\title{
RRAS wt Allele
}

National Cancer Institute

\section{Source}

National Cancer Institute. RRAS wt Allele. NCI Thesaurus. Code C106071.

Human RRAS wild-type allele is located within 19q13.3-qter and is approximately $5 \mathrm{~kb}$ in length. This allele, which encodes Ras-related protein R-Ras, plays a role in both cytoskeletal rearrangement and angiogenesis. 